\title{
Komunikasi Suara Sinyal Digital Dengan Transmisi Frekuensi 2,4 Ghz
}

\author{
Ahmad Wahyu Purwandi \\ PS Teknik Telekomunikasi / T. Elektro \\ Politeknik Negeri Malang \\ Malang, Indonesia \\ ahmad.wahyu@polinema.ac.id
}

\author{
Abdul Rasyid \\ PS Teknik Telekomunikasi / T. Elektro \\ Politeknik Negeri Malang \\ Malang, Indonesia \\ abdul.rasyid@polinema.ac.id
}

\author{
Guntur Wahyu Sejati \\ PS Teknik Telekomunikasi / T. Elektro \\ Politeknik Negeri Malang \\ Malang, Indonesia \\ bledexwahyu@gmail.com
}

\begin{abstract}
The limitations of developing high-tech communication systems cause the area of people who can use this service to be uneven. One technology that can be used for areas not yet reached by this high-tech communication service is to use radio communication technology.

Today radio communication technology continues to develop and produce an increasingly limited frequency spectrum. One way to improve the efficient use of available frequency spectrums is the transition from analog technology to digital technology. A very significant benefit in the use of digital technology is to save the use of radio frequency spectrum bandwidth with signal compression techniques. One device that still uses analog technology is a handy talky (HT). In addition to the lack of frequency spectrum efficiency, HT technology still requires a radio station license (ISR) for its use.

This experiment designed a two-way digital audio communication system that was transmitted using the NRF24L01 radio frequency transceiver module on the $2.4 \mathrm{Ghz}$ frequency. Analog input data from the microphone will be converted into digital data through the ADC (Analog to Digital Converter) process using a microcontroller and the digital data that will be sent is first digitally modulated using GFSK modulation then transmitted digitally. On the other hand data that already contains voice information received again by another NRF24L01 transceiver is received by the Arduino microcontroller and then formed into a PWM signal (pulse width modulation) and then released to the speaker. So the method of using digital transmission can produce efficiencies in the frequency spectrum.
\end{abstract}

Keywords - components; Digital audio; frequency spectrum; transceiver; NRF24L01; GFSK; PWM;

Abstrak - Keterbatasan pembangunan sistem komunikasi teknologi tinggi menyebabkan ketidakmerataan wilayah dari masyarakat yang dapat menggunakan layanan tersebut. Salah satu teknologi yang dapat digunakan untuk wilayah yang belum terjangkau layanan komunikasi dengan teknologi tinggi itu adalah dengan menggunakan teknologi komunikasi radio.

Saat ini teknologi komunikasi radio terus berkembang dan mengakibatkan semakin terbatasnya spektrum frekuensi yang tersedia. Salah satu cara untuk meningkatkan efisiensi penggunaan spektrum frekuensi yang tersedia adalah peralihan dari teknologi analog ke teknologi digital. Manfaat yang sangat berarti dalam penggunaan teknologi digital ialah menghemat penggunaan lebar pita spektrum frekuensi radio karena adanya teknik kompresi terhadap sinyal tersebut. Salah satu perangkat yang masih menggunakan teknologi analog adalah handie talkie (HT). Selain kurangnya efisiensi spektrum frekuensi, teknologi HT masih membutuhkan izin stasiun radio (ISR) untuk penggunaannya.

Penelitian ini merancang sistem komunikasi audio digital dua arah yang ditransmisikan menggunakan modul radio frekuensi transceiver NRF24L01pada frekuensi $2,4 \mathrm{Ghz}$. Data intput analog dari mikrofon akan diubah menjadi data digital melalui proses ADC (Analog to Digital Converter) menggunakan mikrokontroler dan data digital yang akan ditransmisikan terlebih dahulu dimodulasi digital menggunakan modulasi GFSK kemudian ditransmisikan secara digital. Pada sisi lain data yang sudah berisi informasi suara yang diterima lagi oleh transceiver NRF24L01 yang lain diterima oleh mikrokontroler Arduino lalu dibentuk menjadi sinyal PWM (pulse wide modulation) kemudian keluarkan menuju speaker. Sehingga dengan metode menggunakan transmisi digital ini dapat dihasilkan efisiensi pada spektrum frekuensi.

Keyword-komponen; Audio digital; spektrum frekuensi; transceiver; NRF24L01; GFSK; PWM;

\section{PENDAHULUAN}

Layanan komunikasi merupakan kebutuhan pokok bagi masyarakat di era globalisasi seperti saat ini. Layanan komunikasi saat ini semakin berkembang dan canggih. Namun keterbatasan pembangunan sistem komunikasi teknologi tinggi menyebabkan ketidak merataan wilayah dan masyarakat yang dapat menikmati layanan tersebut. Teknologi yang dapat digunakan di wilayah yang belum terjangkau layanan komunikasi dengan teknologi tinggi adalah teknologi radio.

Radio merupakan teknologi yang digunakan untuk pengiriman sinyal dengan cara modulasi dan radiasi elektromagnetik (gelombang elektromagnetik). Gelombang ini melintas dan merambat lewat udara bebas. Penggunaan teknologi radio sebagai media transmisi di Indonesia diatur oleh kementerian komunikasi dan informatika. Radio juga memilki peranan strategis dalam pengembangan jaringan telekomunikasi, termasuk pembangunan jaringan pita lebar, dukungan komunikasi untuk keperluan pertahanan dan keamanan negara, penanggulangan bencana, pencarian dan pertolongan, serta sebagai sarana komunikasi untuk keperluan internal perusahaan, badan hukum, maupun instansi pemerintah. Saat ini teknologi komunikasi radio terus berkembang dan mengakibatkan semakin terbatasnya spektrum frekuensi yang tersedia. Salah satu cara untuk meningkatkan efisiensi penggunaan spektrum frekuensi yang tersedia adalah peralihan dari teknologi analog ke teknologi digital. Yang menjadi Latar Belakang diajukan judul ini adalah karena penulis melihat manfaat yang sangat berarti dalam penggunaan teknologi digital ini yang menghemat penggunaan lebar pita spektrum frekuensi radio karena adanya teknik kompresi terhadap sinyal tersebut (Amry, 2015). Salah satu perangkat yang masih menggunakan teknologi analog adalah handie talkie (HT). Selain kurangnya efisiensi spektrum frekuensi, teknologi HT masih membutuhkan izin stasiun radio (ISR) untuk penggunaannya.

Pada penelitian ini akan dirancang sistem komunikasi audio digital dua arah yang ditransmisikan menggunakan modul radio frekuensi pada frekuensi 2,4Ghz. Data intput analog dari mikrofon akan diubah menjadi data digital melalui proses ADC (Analog to Digital Converter) menggunakan arduino dan data digital yang akan 
ditransmisikan terlebih dahulu dimodulasi digital menggunakan modulasi GFSK yang kemudian ditransmisikan menggunakan transceiver NRF24L01 dengan frekuensi 2,4Ghz. Pada sisi lain data yang diterima oleh transceiver akan dikeluarkan melalui speaker dengan menggunakan modulasi pulse wide modulation (PWM) pada arduino. Sehingga dengan modulasi digital diharapkan efisiensi spektrum frekuensi dapat tercapai. Selain itu menurut laman web resmi direktorat jenderal sumber daya dan perangkat pos dan informatika tentang izin spektrum frekuensi radio menyatakan bahwa penggunaan frekuensi 2,4 Ghz masuk dalam kategori izin kelas yang tidak membutuhkan izin stasiun radio (ISR), sehingga pada sistem yang dibuat dapat digunakan tanpa membutuhkan ISR.

\section{METODE PENELITIAN}

Penelitian ini adalah jenis Eksperiment yang menjelaskan tentang rancangan sistem, cara kerja sistem dan perencanaan dalam pembuatan Penelitian ini berjudul "Komunikasi Suara Sinyal Digital Dengan Transmisi Frekuensi 2,4 Ghz".

\section{Alur Penelitian}

Rancangan penelitian disusun agar proses penelitian dapat dilakukan secara bertahap dan terstruktur. Rancangan penelitian yang akan dilakukan ditunjukkan pada Gambar berikut.

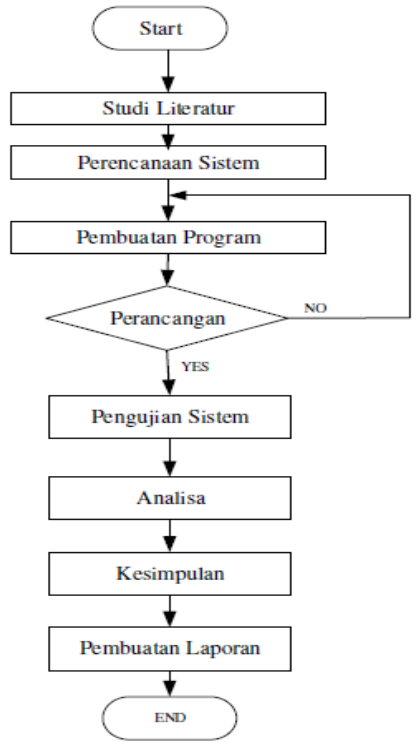

Gambar 1 Rancangan Penelitian

Tahapan Penelitian yang dilakukan dalam penelitian ini adalah sebagai berikut:

1. Studi literatur tentang pembuatan sistem dan analisa proses komunikasi radio menggunakan mikrokontroler arduino dan modul radio frekuensi nrf 24101.

2. Perencanaan sistem kerja dari sistem yang akan dibuat. Di tahapan ini ditulis langkah-langkah kerja dari sistem yang akan dibuat.

3. Pembuatan program pada mikrokontroler arduino.

4. Perancangan dilakukan untuk merancang alat yang akan dibuat dan memasukkan script program, apabila script program yang dibuat tidak berjalan semestinya maka kembali membuat program. Apabila program sudah berjalan maka program bisa digunakan.

5. Pengujian sistem dilakukan untuk mengetahui sistem sudah berjalan sesuai rencana atau belum.

6. Menganalisa program dan alat yang dibuat sudah berfungsi dengan baik atau belum.

7. Pembuatan kesimpulan bedasarkan analisa yang dibuat

8. Pembuatan laporan

Blok Diagram

Blok diagram perencanaan sistem ditunjukkan pada Gambar 3.2.

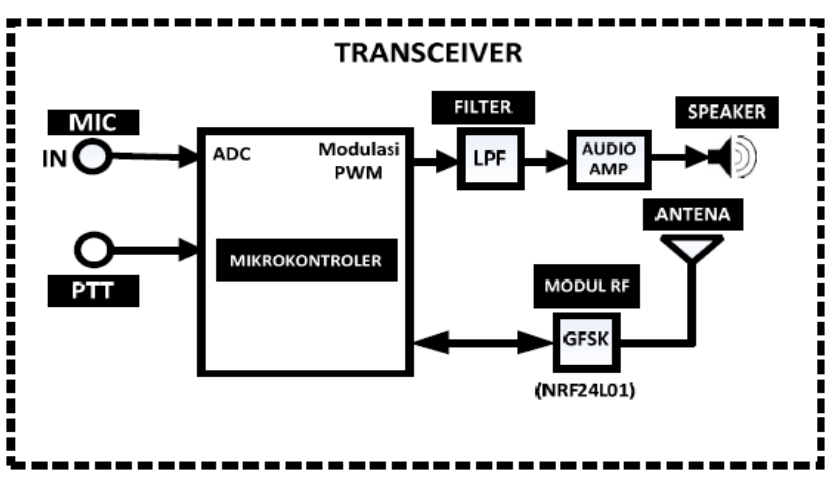

Gambar 2 Blok Diagram Perencanaan Sistem

Pembuatan perangkat sistem komunikasi audio digital dua arah half duplex digambarkan dalam bentuk blok diagram yang ditunjukkan pada gambar 2 .

Terlihat dari blok diagram tersebut bahwa perangkat yang akan dibuat dibagimenjadi tujuh blok yaitu, mikrokontroler arduino uno, mikrofon max9814,rangkaian push to talk, modul radio frekuensi nrf24101, lowpass filter, penguataudio dan speaker. Setiap blok tersebut memiliki fungsi masing- masing. Fungsifungsinyaadalah sebagai berikut:

1. Mikrokontroler (Arduino Uno)

Board Arduino Uno berfungsi sebagai mikrokontroler utama para system yang akan dibuat. Hal tersebut ditunjukan pada diagram blok bahwa Arduino terhubung secara langsung dengan blok yang lain.

3. Mikrofon $\max 9814$

Mikrofon max9814 adalah mikrofon dilengkapi dengan preamplifier low noise, variable gain amplifier (VGA), penguat keluaran, generator tegangan biasmikrofon dan sirkuit kontrol AGC. Mikrofon ini berfungsi sebagai intput suara pada system 4 . Rangkaian push to talk

Rangkain push to talk ini berfungsi sebagai tombol saat sistem yang dibuat akan digunakan untuk proses komunikasi. Rangkaian ini dirangkai dengan LED dioda yang berfungsi sebagai pemberitahuan bahwa sistem sedang berfungsi sebagai transmitter. 5. Transceiver nrf 24101

Transceiver nrf24101 berfungsi sebagai modul radio frekuensi yang dapat berfungsi sebagai pengirim dan penerima. Pada transceiver ini menggunakan modulasi GFSK dan bekerja pada frekuensi 2,4Ghz.

6. Low Pass Filter

Filter ini berfungsi untuk menyaring frekuensi noise yang berada diatas frekuensi audio. Filter yang dirancang menggunakan jenis filter low pass dengan frekuensi cut off $4080,8 \mathrm{~Hz}$

7. Penguat Audio

Penguat audio ini berfungsi untuk menguatkan informasi audio yang telah disaring oleh filter low pass.

8. Speaker

Speaker merupakan bagian blok yang berfungsi sebagai perangkat untuk mengeluarkan suara yang telah diterima melalui NRF24L01. Informasi yang telah diperoleh tersebut akan dikeluarkan melalui speaker dengan menggunakan modulasi pulse wide modulation (PWM) pada arduino.

\section{Diagram Alir Sistem}

Diagram alir sistem ini menjelaskan tentang cara kerja sistem yang akan dibuat. Diagram alir sistem ditunjukan pada Gambar berikut.

Dalam rancangan alat terdapat tiga fungsi utama yaitu :

1. Data intput dari mikrofon diolah ke data digital oleh mikrokontroler arduino

2. Data hasil pemrosesan dikirimkan oleh modul transceiver nrf24101

3. Data yang diterima oleh transceiver nrf2401 diolah oleh arduino dan dikeluarkan melalui speaker 


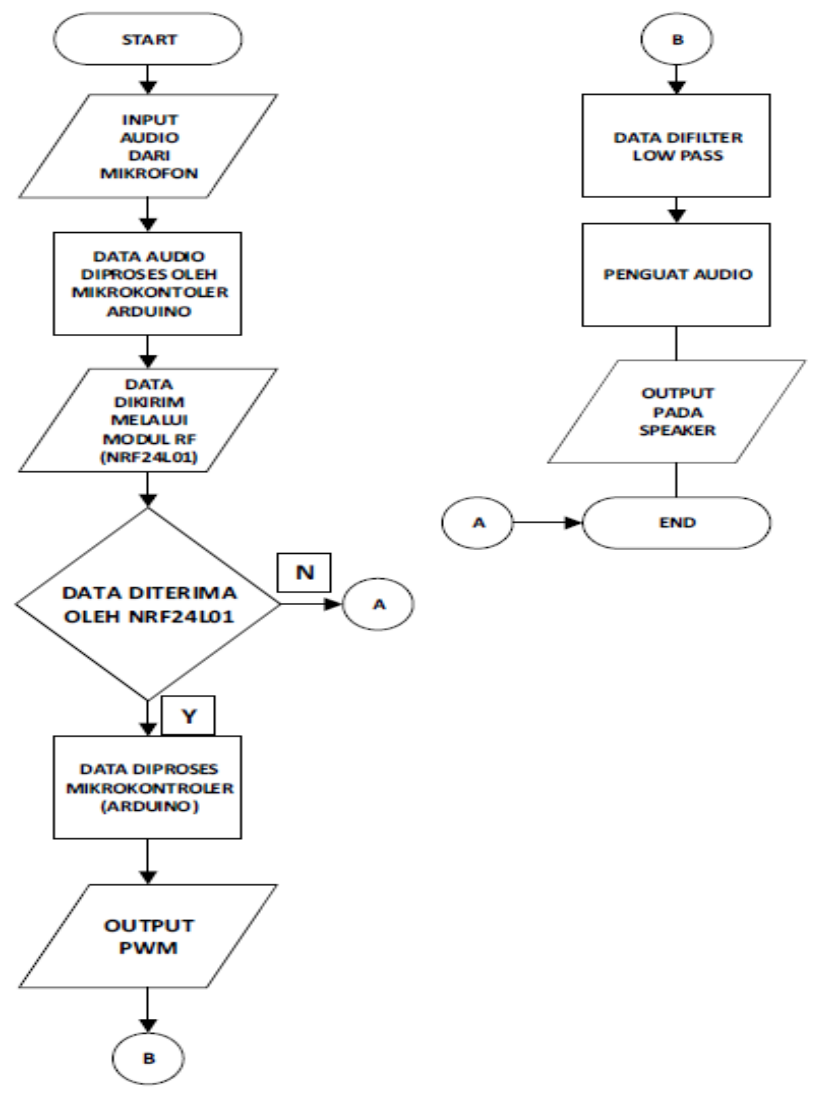

Gambar 3 Diagram Alir Sistem

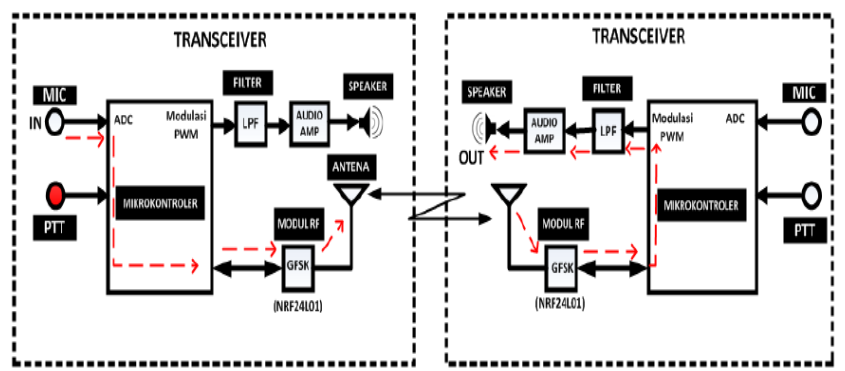

Gambar 4 Prinsip Kerja Sistem

Prinsip kerja sistem yang ditunjukkan pada gambar diatas. Jenis komunikasi yang digunakan pada penelitian ini adalah half duplex. Proses komunikasi dimulai dengan menekan tombol PTT (push to talk) pada perangkat pemacar. Saat salah satu perangkat menekan tombol PTT maka perangkat tersebut akan berfungsi sebagai pemancar dan perangkat yang lain akan berfungsi sebagai penerima.

Seperti yang ditunjukkan pada gambar, garis putus-putus merupakan alur informasi dari input sampai dengan output.

Sisi pemancar berfungsi untuk mengirimkan informasi, mikrofon digunakan sebagai perangkat yang menerima input suara. Data analog dari mikrofon akan diubah menjadi data digital melalui proses ADC (Analog to Digital Converter) menggunakan mikrokontroler arduino uno. Data digital tesebut akan dimodulasi dengan modulasi GFSK (Gaussian frequency shift keying) pada transceiver nrf24101. Data hasil modulasi kemudian diubah menjadi sinyal elektromaknetik dan dipropagasikan oleh antena.

Sisi penerima berfungsi untuk menerima informasi, sinyal elektromaknetik yang dipropagasikan oleh antena pemancar akan diterima dan diubah menjadi sinyal listrik oleh antena penerima. Sinyal listrik dalam bentuk data analog didemodulasi oleh transceiver nrf24101 menjadi data digital. Data digital tersebut dimudulasi PWM (Pulse width modulation) oleh mikrokontroler.
Kemudian data digital PWM akan dimasukkan kedalam low pass filter untuk menyaring noise yang terdapat pada data digital PWM kedalam bentuk sinyal analog. Sinyal analog tersebut dikuatkan menggunakan penguat audio dan hasil keluaran penguat audio akan dikeluarkan oleh speaker.

\section{Perancangan dan Pembuatan Hardware}

Pada perangkat transceiver, mikrokontroler yang utama adalah arduino uno. Setiap komponen yang digunakan seperti mikrofon max9814, modul radio

frekuensi nrf24101, tombol PPT (push to talk), dan speaker. Skema rangkaian

ditunjukkan pada Gambar 3.5.

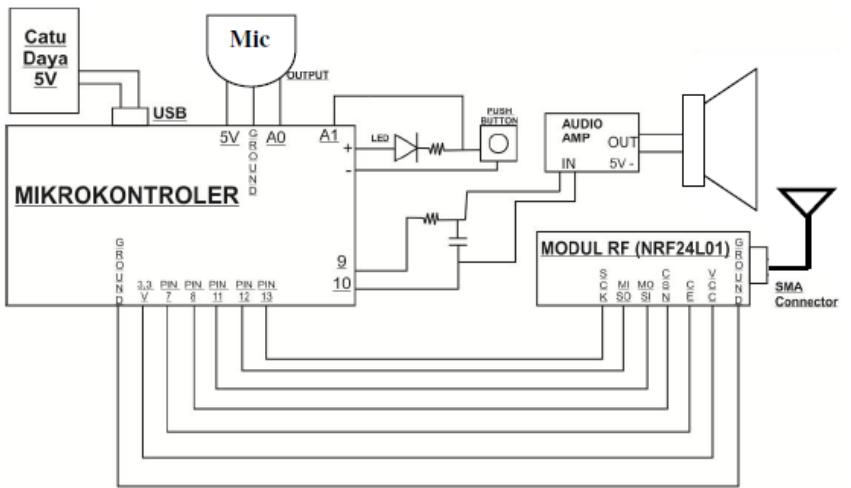

Gambar 5 skema rangkaian sistem

\section{a. Pemasangan Mikrofon Max9814}

Pin output perangkat mikrofon Max9814 dipasangkan pada pin analog A0 pada board Arduino Uno, tegangan mikrofon dihubungkan pada pin 5V Arduino dan ground. Rangkaian pemasangan mikrofon ditunjukkan pada gambar 3.6.

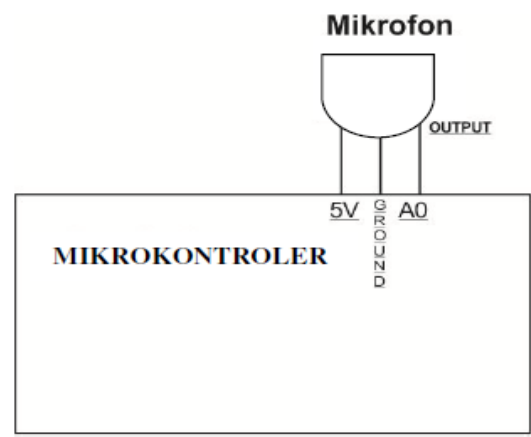

Gambar 6 Skema pemasangan mikrofon

\section{b. Pemasangan Rangkain Push to Talk}

Rangkaian push to talk yang digunakan terdiri dari push button, led diode, dan resistor. Rangkaian push to talk terpasang pada pin A1 pada board Arduino Uno. Gambar 3.7 menunjukkan rangkaian push to talk yang digunakan.

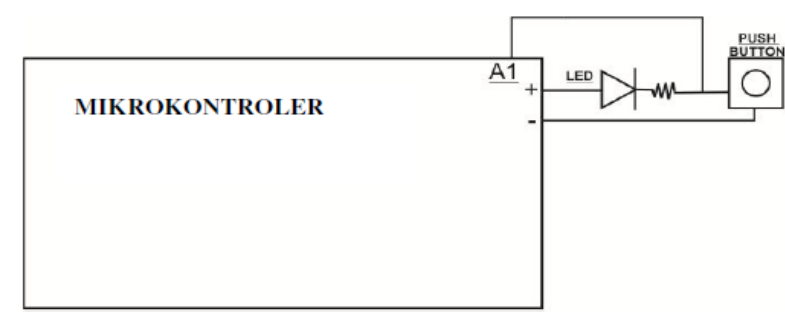

Gambar 7 Skema pemasangan rangkaian push to talk c. Pemasangan Modul RF (nrf24101)

Pemasangan nrf24101 menggunakan pin serial peripheral interface (SPI).

Tegangan yang dibutuhkan oleh nrf24101 adalah sebesar 3,3V. Sedangkan pin yang digunakan pada Arduino ditunjukkan pada gambar. 


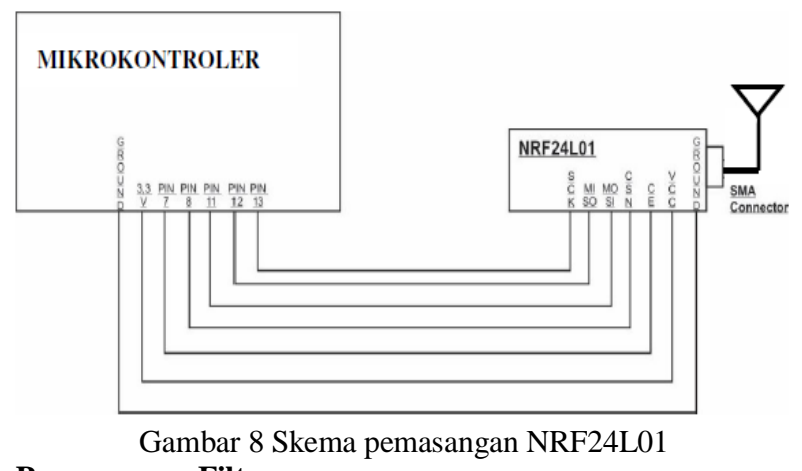

d. Perancangan Filter

Pembuatan filter bertujuan untuk mengurangi noise pada output PWM dari mikrokontroler. Jenis filter yang akan dibuat adalah filter LPF (low pass filter). Skema perancangan filter ditunjukkan pada Gambar.

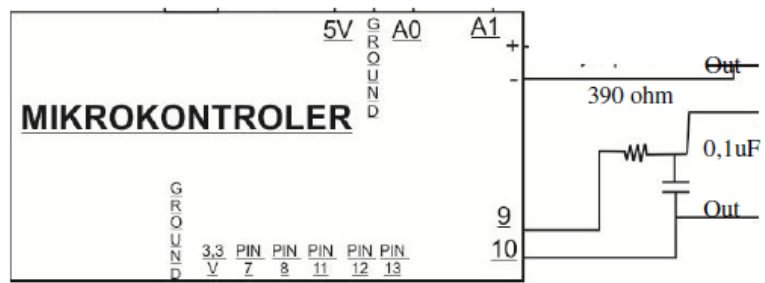

Gambar 9 Skema Perancangan Filter

Komponen yang digunakan yaitu resistor $390 \mathrm{Ohm}$ dan kapasitor 0.1 mikroFarad. Perhitungan frekuensi cutoff sebagai berikut :

$$
\begin{aligned}
& F^{\prime} c=\frac{1}{2 \pi R C} \\
& F_{C}=\frac{1}{2 \times 3,14 \times 3900 \times 0,1 \mu F}
\end{aligned}
$$$$
\mathrm{Fc}=4080,8 \mathrm{~Hz}
$$

\section{e. Pemasangan Penguat Audio Pam8403}

Penguat audio pam 8403 berfungsi sebagai penguat sinyal audio setelah melewati filter low pass. Jenis penguat audio yang digunakan adalah pam8403. Pemasangan penguat audio pam 8403 ditunjukkan pada Gambar.

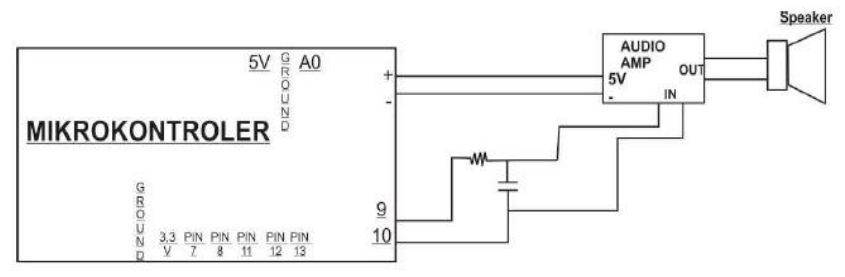

Gambar 10 Pemasangan Penguat Audio Pam8403

\section{f. Pemasangan Speaker}

Speaker pada penelitian ini berfungsi sebagai bagian output akhir dari perangkat. Sinyal audio yang telah melewati filter low pass dan penguat audio akan dikeluarkan oleh speaker menjadi suara. Skema pemasangan speaker ditunjukkan pada gambar.

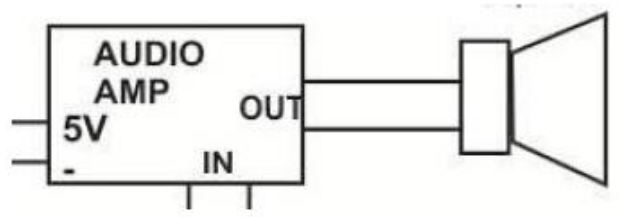

Gambar 11 Skema Pemasangan Speaker

\section{Perancangan dan Pembuatan Software}

Pada pembuatan sistem ini, selain perancangan perangkat keras juga dirancang program untuk arduino dengan menggunakan software IDE Arduino.

Pada perangkat transceiver, program yang telah dibuat akan diupload pada arduino Uno melalui software IDE Arduino. Diagram alir perancangan software ditunjukkan pada Gambar 3.13.

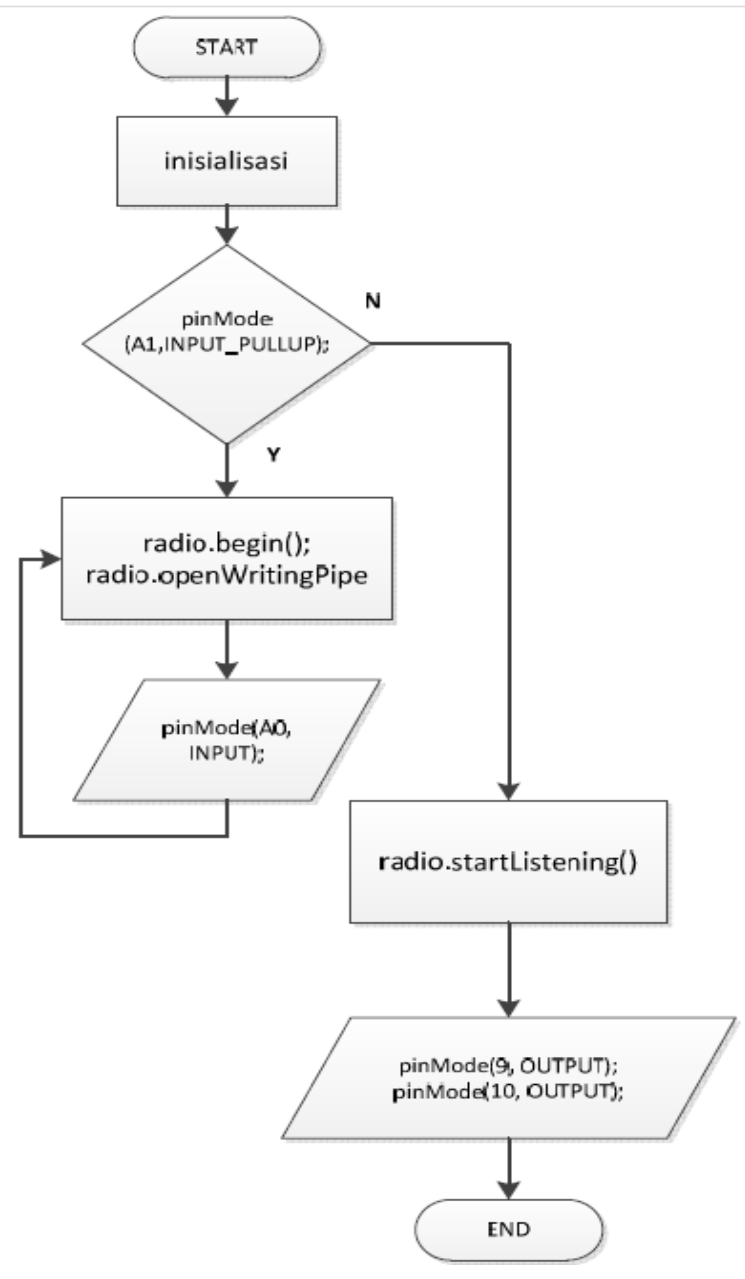

Gambar 12 Diagram alir perancangan software

Proses komunikasi dimulai saat salah satu perangkat menekan tombol push to talk

dengan fungsi pin A1 sebagai input pullup, saat tombol PTT ditekan maka modul

RF nrf24101 akan menjalankan fungsi sebagai pemancar dengan menjalankan fungsi radio.begin(); . Saat PTT ditekan mikrofon akan aktif sebagai input pada pin A0. Sisi penerima akan berfungsi sebagai penerima dengan menjalankan fungsi radio.startListening(). Kemudian dikeluarkan menggunakan pin PWM 9 dan 10 pada mikrokontroler.

Perancangan Dan Pembuatan Program Dengan IDE Arduino Sebelum program di-upload, dilakukan pengecekan port yang digunakan perangkat arduino untuk terhubung dengan komputer. Pengecekan dilihat pada menu "Tools" _ "Port". 


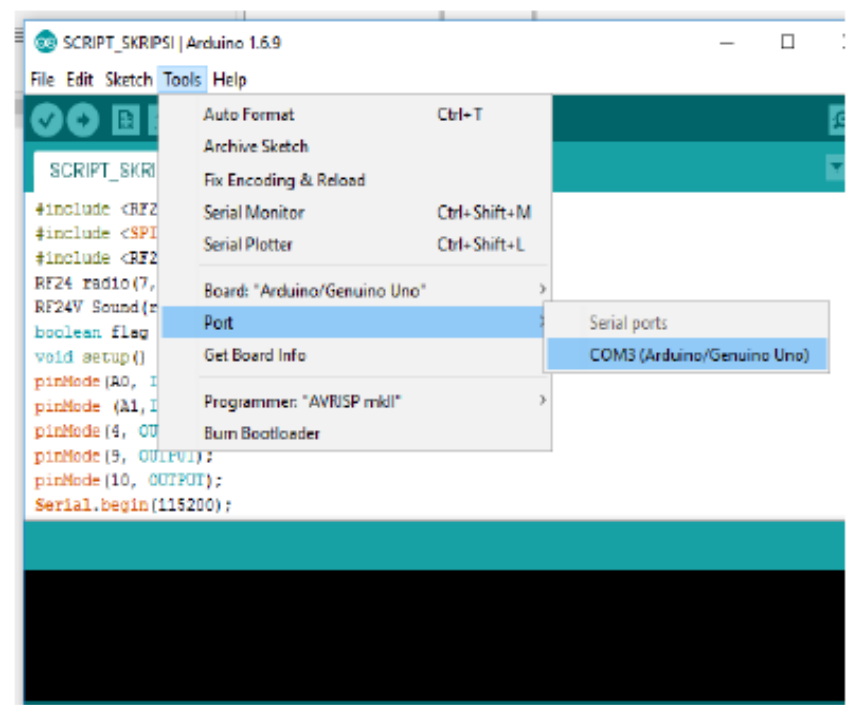

Gambar 13 Pengecekan port Arduino Uno

Setelah port telah terhubung, maka proses selanjutnya adalah pengecekan

listing program. Pengecekan ini dapat dilakukan dengan menekan icon centang atau "verify"

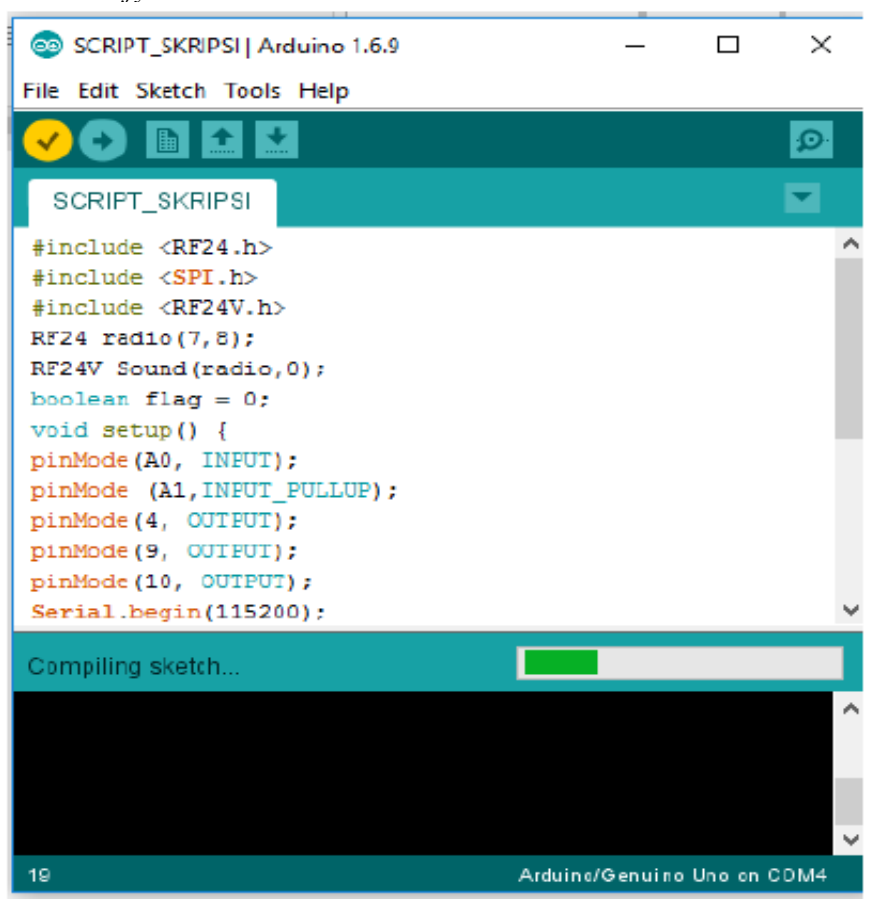

Gambar 14 Proses verify sedang berjalan

Proses verify selesai saat terdapat pemberitahuan "Done Compiling" pada bagian bawah IDE Arduino.

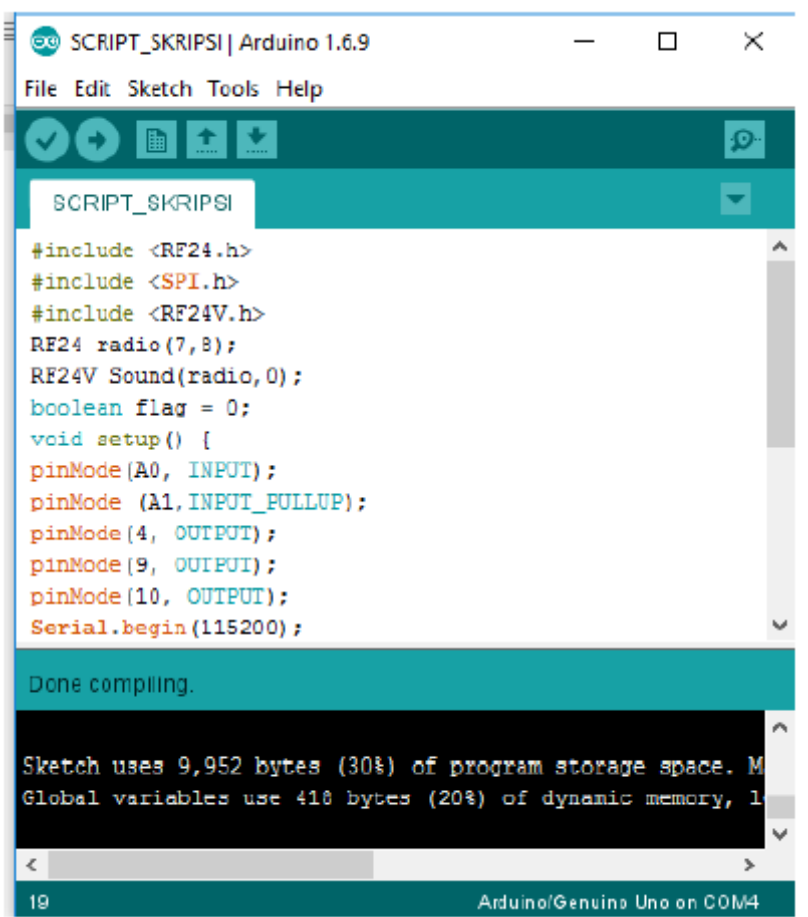

Gambar 15 Proses verify selesai

Jika tidak terdapat error saat proses "verify" maka program siap untuk di-upload.

Proses upload dapat dilakukan dengan menekan icon panah yang terdapat pada bagian atas IDE Arduino.

(6) SCRIPT_SKRIPSI| Arduino 1.6.9

File Edit Sketch Tools Help

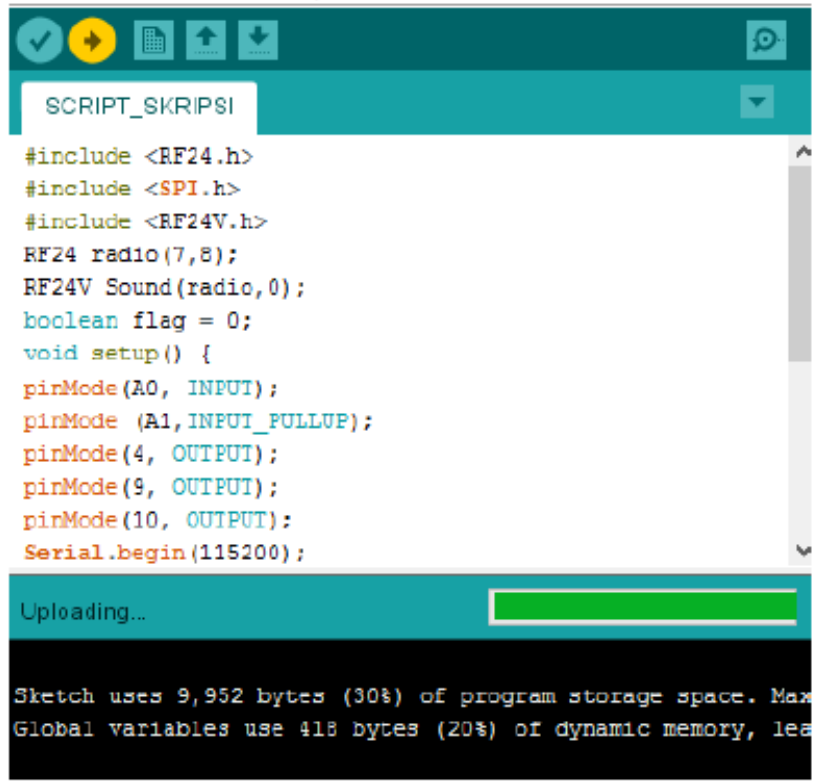

Gambar 16 Proses upload program Arduino Uno

Proses upload dianggap selesai jika terdapat pemberitahuan "done uploading" pada bagian bawah IDE Arduino dan apabila tidak terdapat pesan error. 


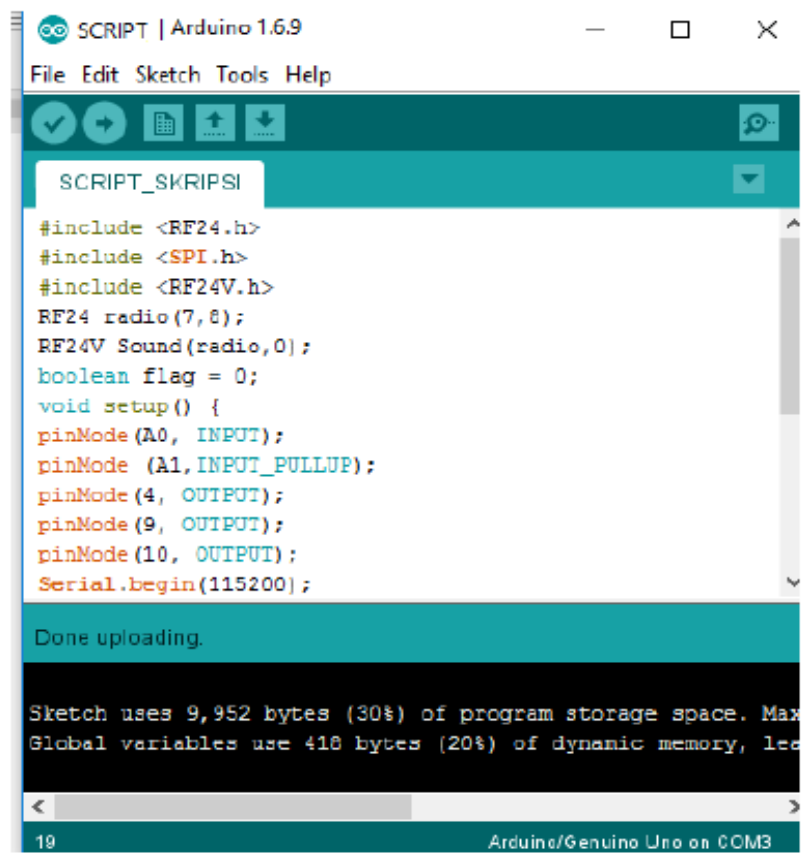

Gambar 17 Proses upload program Arduino Uno selesai Metode Rancangan Pengujian

Pengujian sistem dilakukan pada beberapa parameter yang berkaitan dengan sistem pengolahan dan pengirim data, diantaranya:

1. Pengujian readability: Pada tahap ini dilakukan pengujian kemampuan sistem dalam pembacaan/ pengenalan informasi yang telah diterima oleh receiver.

2. Pengujian jarak jangkauan: Pada tahap ini pengujian dilakukan untuk mengetahui jarak jangkauan yang dapat dicapai oleh sistem yang telah dibuat.

3. Pengujian kualitas hasil sinyal output : Pada tahap ini pengujian dilakukan untuk mengetahui hasil sinyal yang telah diterima oleh penerima dan membandingkan sinyal tersebut dengan sinyal yang dikirimkan.

\section{HASIL DAN PEMBAHASAN}

Bab keempat ini menjelaskan tentang hasil pengujian dan pembahasan dari sistem yang telah dibuat yaitu "Perancangan Sistem Komunikasi Audio Digital Dua Arah Half Duplex Dengan Mikrokontroler Pada Frekuensi 2,4 Ghz". Pengujian sistem bertujuan untuk mengetahui bahwa sistem yang telah dibuat sesuai dengan perancanaan.

\section{Hasil Implementasi Alat}

Implementasi alat dibuat sesuai dengan perencanaan yang telah dirancang. Perangkat arduino uno berfungsi sebagai mikrokontroler utama untuk memasangkan perangkat lain seperti mikrofon max9814, tombol PTT(push to talk), modul transceiver NRF24L01 dan speaker sbagai output suara. Perangkat speaker, mikrofon, push button dipasangkan pada box bagian atas seperti pada gambar.

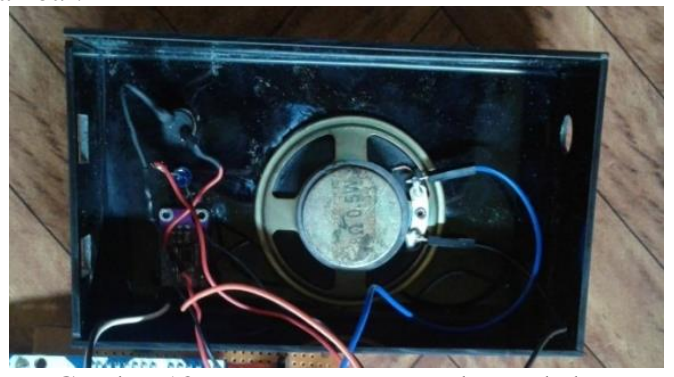

Gambar 18 Pemasangan perangkat pada box
Perangkat Arduino dipasangkan pada bagian bawah box sehingga hasil pengemasan sistem seperti pada gambar 4.2.

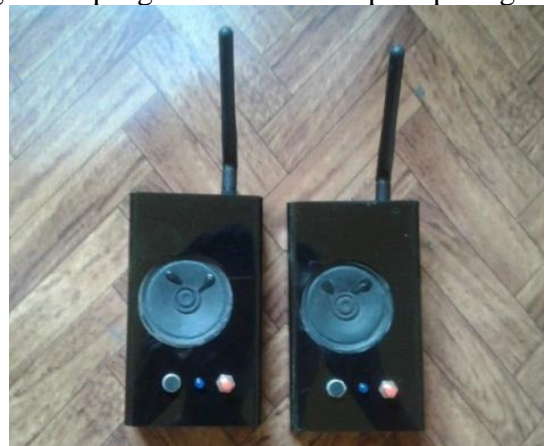

Gambar 19 Hasil pengemasan perangkat menggunakan box Metode Pengujian dan Pembahasan

Pada penelitian ini pengujian yang dilakukan meliputi pengujian readability atau kemampuan pembacaan informasi suara yang diterima oleh receiver, pengujian jarak jangkauan sistem, dan

\section{Hasil Pengujian} pengujian hasil sinyal output pada sistem.

\section{Pengujian Readability (Keterbacaan) Sistem}

Pada pengujian ini bertujuan untuk mengetahui tingkat keterbacaan dari informasi suara yang telah dikirimkan oleh transmitter ke receiver. Pengujian ini dilakukan dengan cara menerjemahkan informasi yang diterima dengan menggunakan aplikasi voice to text (speech texter) pada receiver dan melakukan perhitungan presentase keberhasilan hasil pembacaan. Output

speaker pada receiver dihubungkan dengan komputer menggunakan jack audio 3,5 mm. Lalu memilih menu "start" pada aplikasi speech texter untuk memulai proses penerjemahan.
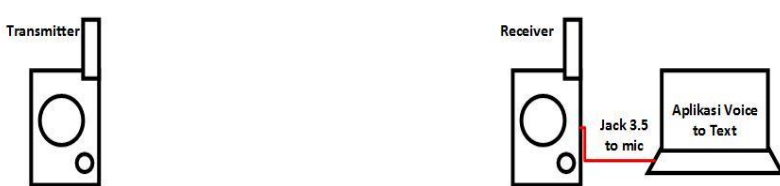

Gambar 20 Diagram blok proses pengujian readabilty system

Aplikasi yang digunakan adalah aplikasi speechtexter pada google crome. Salah satu contoh hasil penerjemahan informasi yang diterima seperti gambar.

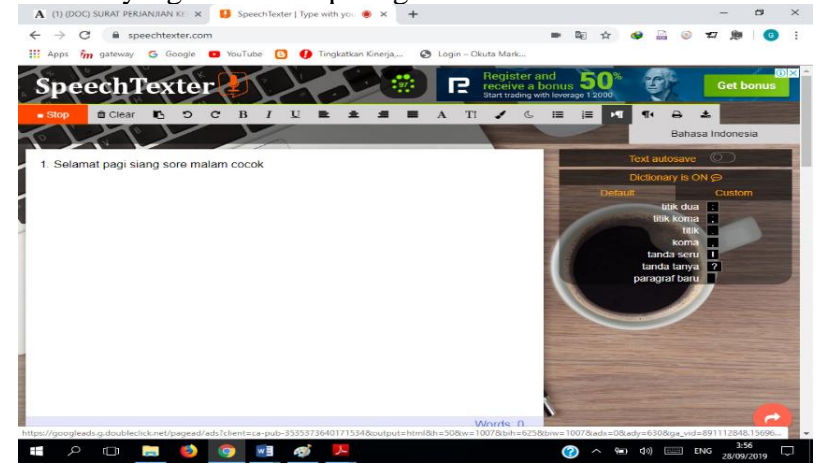

Gambar 21 Hasil penerjemahan informasi yang diterima menggunakan Speechtexter

Hasil pengujian readability sistem ditunjukkan pada Tabel sebagai berikut:

Tabel 1 Pengujian Readability Sistem

\begin{tabular}{|c|c|c|c|c|}
\hline No. & Huruf & $\begin{array}{c}\text { Kata yang } \\
\text { diucapkan }\end{array}$ & $\begin{array}{c}\text { Kata yang } \\
\text { ditulis }\end{array}$ & $\begin{array}{c}\text { Presentase } \\
\text { keberhasilan }\end{array}$ \\
\hline 1. & \multirow{2}{*}{$\mathrm{A}$} & Apa & Apa & $100 \%$ \\
\cline { 3 - 5 } & & Amfibi & Amfibi & $100 \%$ \\
\cline { 3 - 5 } & & Andalan & Andalan & $100 \%$ \\
\hline 2. & $\mathrm{~B}$ & Belajar & Belajar & $100 \%$ \\
\hline
\end{tabular}


Jurnal Teknologi Informasi dan Terapan (J-TIT) Vol. 6 No. 2 Juli-Desember 2019 ISSN: 2580-2291

\begin{tabular}{|c|c|c|c|c|}
\hline & & Bekas & Bekas & $100 \%$ \\
\hline \multirow[t]{2}{*}{3.} & \multirow[t]{2}{*}{$\mathrm{C}$} & Cantik & Cantik & $100 \%$ \\
\hline & & Cerdas & Cerdas & $100 \%$ \\
\hline \multirow[t]{2}{*}{4.} & \multirow{2}{*}{$\mathrm{D}$} & Dasar & Dasar & $100 \%$ \\
\hline & & Dinding & Dinding & $100 \%$ \\
\hline \multirow[t]{2}{*}{5.} & \multirow[t]{2}{*}{$E$} & Enak & Enak & $100 \%$ \\
\hline & & Enter & Enter & $100 \%$ \\
\hline \multirow[t]{2}{*}{6.} & \multirow[t]{2}{*}{$\mathrm{F}$} & Firasat & Firasat & $100 \%$ \\
\hline & & Fitrah & Fitrah & $100 \%$ \\
\hline \multirow[t]{2}{*}{7.} & \multirow[t]{2}{*}{$\mathrm{G}$} & Ganteng & Ganteng & $100 \%$ \\
\hline & & Gunting & Gunting & $100 \%$ \\
\hline \multirow[t]{2}{*}{8.} & \multirow[t]{2}{*}{$\mathrm{H}$} & Harapan & Harapan & $100 \%$ \\
\hline & & Hidrogen & Hidrogen & $100 \%$ \\
\hline \multirow[t]{2}{*}{9.} & \multirow[t]{2}{*}{ I } & Intan & Intan & $100 \%$ \\
\hline & & Irama & Irama & $100 \%$ \\
\hline \multirow[t]{2}{*}{10.} & \multirow[t]{2}{*}{$\mathrm{J}$} & Jambu & Jambu & $100 \%$ \\
\hline & & Jinak & China & $60 \%$ \\
\hline \multirow[t]{2}{*}{11.} & \multirow[t]{2}{*}{$\mathrm{K}$} & Kamu & Kamu & $100 \%$ \\
\hline & & Kita & Kita & $100 \%$ \\
\hline \multirow[t]{2}{*}{12.} & \multirow[t]{2}{*}{$\mathrm{L}$} & Lama & Lama & $100 \%$ \\
\hline & & Listrik & Listrik & $100 \%$ \\
\hline \multirow[t]{2}{*}{13.} & \multirow[t]{2}{*}{$\mathrm{M}$} & Masjid & Masjid & $100 \%$ \\
\hline & & Minum & Minum & $100 \%$ \\
\hline \multirow[t]{2}{*}{14.} & \multirow[t]{2}{*}{$\mathrm{N}$} & Niat & Niat & $100 \%$ \\
\hline & & Nanti & Nanti & $100 \%$ \\
\hline \multirow[t]{2}{*}{15.} & \multirow[t]{2}{*}{$\mathrm{O}$} & Orang & Orang & $100 \%$ \\
\hline & & Otak & Otak & $100 \%$ \\
\hline \multirow[t]{2}{*}{16.} & \multirow[t]{2}{*}{$\mathrm{P}$} & Paha & Paha & $100 \%$ \\
\hline & & Piranha & Piranha & $100 \%$ \\
\hline 17. & $\mathrm{Q}$ & Quran & Quran & $100 \%$ \\
\hline & & Qurban & Qurban & $100 \%$ \\
\hline 18. & $\mathrm{R}$ & Rasa & Rasa & $100 \%$ \\
\hline & & Riang & Riang & $100 \%$ \\
\hline 19. & $\mathrm{~S}$ & Sapu & Sapu & $100 \%$ \\
\hline & & Soda & Soda & $100 \%$ \\
\hline 20. & $\mathrm{~T}$ & Tahu & Tahu & $100 \%$ \\
\hline & & Tempe & Tempe & $100 \%$ \\
\hline 21. & $\mathrm{U}$ & Udang & Undang & Error $20 \%$ \\
\hline
\end{tabular}

\begin{tabular}{|c|c|c|c|c|}
\hline & & Uranium & Uranium & $100 \%$ \\
\hline 22. & $\mathrm{~V}$ & Visi & Visi & $100 \%$ \\
\cline { 3 - 5 } & & Verbal & Verbal & $100 \%$ \\
\hline 23. & $\mathrm{~W}$ & Warung & Warung & $100 \%$ \\
\cline { 3 - 5 } & & Wewenang & Wewenang & $100 \%$ \\
\hline 24. & $\mathrm{X}$ & expert & Expert & $100 \%$ \\
\cline { 3 - 5 } & & expensive & expensive & $100 \%$ \\
\hline 25. & $\mathrm{Y}$ & Yaitu & Yaitu & $100 \%$ \\
\cline { 3 - 5 } & & Yes & Yes & $100 \%$ \\
\hline 26 & \multirow{2}{*}{$\mathrm{Z}$} & Zebra & Zebra & $100 \%$ \\
\cline { 3 - 5 } & & Zaman & Zaman & $100 \%$ \\
\hline
\end{tabular}

Dari data hasil pengujian pada table menunjukkan bahwa sistem dapat menerjemahkan informasi yang telah diterima secara tepat untuk informasi dengan presentase keberhasilan sebesar $100 \%$. Sedangkan untuk kata-kata dengan sample kata "Jinak" yang mewakili huruf "J" masih memiliki tingkat keberhasilan sebesar $60 \%$ karena data yang diterima menjadi kata "china" dan error sebesar $20 \%$ pada sample kata "Udang" yang menjadi "undang". Perhitungan presentase keberhasilan ditunjukkan pada rumus sebagai berikut :

Presentase keberhasilan $=\frac{\text { Jumlah huruf yang dapat terbaca }}{\text { Jumlah huruf dari kata yang dikirimkan }} \times 100 \%$

Macam- macam kata yang digunakan pada table diharapkan dapat mewakili huruf alfabet dari A-Z.

\section{Pengujian Jarak Jangkauan Sistem}

Pengujian ini bertujuan untuk mengetahui jarak maksimal dari sistem yang telah dibuat. Terdapat dua pengujian yang dilakukan yaitu pengujian pengaruh perubahan data rate terhadap jarak jangkauan dan pengujian pengaruh perubahan daya transmisi terhadap jarak jangkauan.

Pengujian Pengaruh Perubahan Data Rate Terhadap Jarak Jangkauan

Pada pengujian ini dilakukan untuk mengukur jarak maksimal proses komunikasi antar transceiver dengan data rate yang berbeda. Sebelum melakukan proses pengujian, terlebih dahulu data rate dari sistem disetting menjadi $250 \mathrm{Kbps}$ dan $1 \mathrm{Mbps}$. Proses setting dilakukan menggunakan IDE Arduino seperti pada gambar,

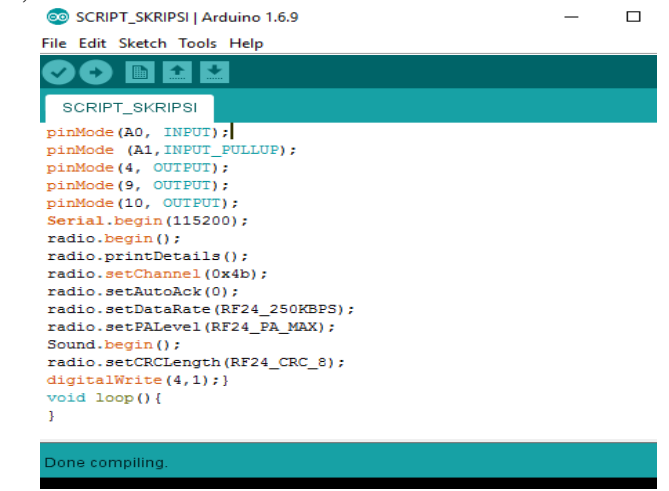

Gambar 22 Setting data rate sistem pada IDE Arduino Proses pengujian dilakukan seperti pada gambar . 


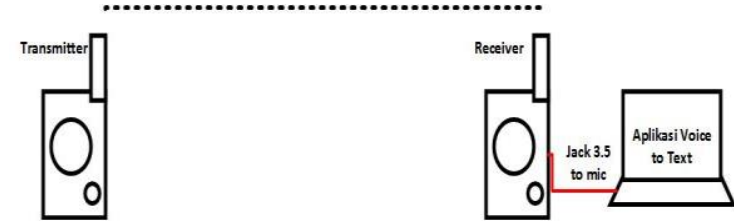

Gambar 23 Diagram blok proses pengujian jangkauan sistem

Pengujian jarak dilakukan dengan cara melakukan intput sample kalimat pada transmitter dan pengencekkan pada sisi receiver dengan menggunakan aplikasi voice to text. Perangkat receiver dihubungkan menggunakan jack $3,5 \mathrm{~mm}$ yang dipasangkan pada port mikrofon komputer. Apabila kalimat yang dikirimkan oleh transmitter dapat diterjemahkan oleh aplikasi voice to text dengan benar pada sisi receiver maka proses komunikasi dianggap berhasil. Sample kalimat yang digunakan adalah sebagai "apa kabar" dan "selamat pagi".

Hasil Pengujian jarak sistem dengan data rate $250 \mathrm{Kbps}$

Dari hasil pengujian pada Tabel dapat digambarkan grafik seperti pada gambar.

\section{GRAFIK PENGUJIAN JARAK}

( DATA RATE 250 KBPS)

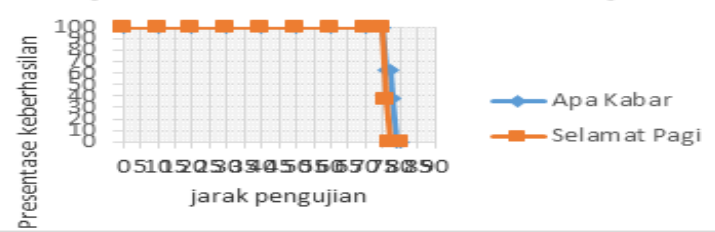

Gambar 24 Gafik pengujian jangkauan dengan datarate $250 \mathrm{Kbps}$ Dari hasil pengujian dengan data rate $1 \mathrm{Mbps}$ dapat digambarkan dalam bentuk grafik yang ditunjukkan pada gambar

\section{GRAFIK PENGUJIAN JARAK} (DATA RATE 1MBPS)

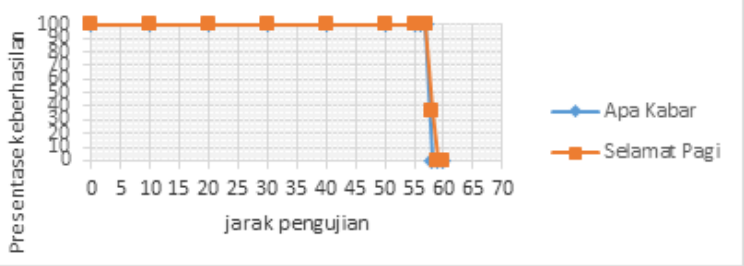

Gambar 25 Grafik pengujian jangkauan dengan datarate 1Mbps

Dari hasil pengujian memiliki perbedaaan hasil jarak jangkauan sistem. Pada pengujian dengan setting data rate $250 \mathrm{Kbps}$ jarak maksimal yang dapat terjangkau oleh sistem yaitu $75 \mathrm{~m}$ dengan presentase keberhasilan $100 \%$. Nilai presentase keberhasilan diperoleh dari perhitungan dengan rumus:

Presentase keberhasilan $=\frac{\text { jumlah huruf yang dapat terbaca }}{\text { jumlah huruf dari kata yang dikirimkan }} \times 100 \%$

Presentase keberhasilan $=\frac{5(\text { Apaka })}{8(\text { Apakabar })} \times 100 \%=62,5 \%$

Pada jarak $76 \mathrm{~m}$ proses komunikasi masih bisa namun data yang diterima tidak sempurna dengan presentase keberhasilan $62,5 \%$ untuk kalimat "apa kabar" dan 36,3\% untuk kalimat "selamat pagi". Sedangkan pada pengujian dengan data rate $1 \mathrm{Mbps}$, jarak maksimal yang dapat dicapai oleh sistem yaitu $55 \mathrm{~m}$ dengan presentase keberhasilan $100 \%$. Pada jarak $56 \mathrm{~m}$ proses komunikasi masih bisa namun data yang diterima tidak sempurna dengan presentase keberhasilan $100 \%$ untuk kalimat "apa kabar" dan 63,6\% untuk kalimat "selamat pagi".

Dari hasil pengujian tersebut dapat disimpulkan bahwa setting data rate $250 \mathrm{Kbps}$ memiliki jarak jangkauan yang lebih jauh sebesar $75 \mathrm{~m}$ dan pada data rate $1 \mathrm{Mbps}$ memiliki jarak yang lebih rendah yaitu sebesar $55 \mathrm{~m}$.
Pengujian Pengaruh Perubahan Daya Transmisi Terhadap Jarak Jangkauan

Pengujian ini bertujuan untuk mengetahui pengaruh perubahan daya transmisi terhadap jarak jangkauan sistem. Metode pengujian yang dilakukan yaitu dengan melakukan setting beberapa jenis daya yang akan digunakan oleh NRF24L01. Setting dilakukan dengan menggunakan script radio.setPALevel(RF24_PA_level) seperti yang ditunjukkan pada gambar

(0) SCRIPT_SKRIPSI|Arduino 1.6.9 $\quad-\quad \square \times$

File Edit Sketch Tools Help

\begin{tabular}{|c|c|}
\hline 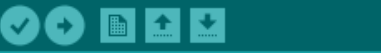 & $\rho$ \\
\hline SCRIPT_SKRIPSI & $\checkmark$ \\
\hline \#include $\langle$ Kr24V.n $\rangle$ & \\
\hline RF24 radio $(7,8)$; & \\
\hline RF24V Sound (radio, 0); & \\
\hline boolean flag $=0$; & \\
\hline void setup() \{ & \\
\hline pinMode $(\mathrm{A} 0$, INPUT) ; & \\
\hline pinMode (A1, INPUT_PULLUP); & \\
\hline pinMode $(4$, OUTPUT $)$; & \\
\hline pinMode $(9$, OUTPUT $)$; & \\
\hline pinMode (10, OUTPUT) ; & \\
\hline Serial.begin (115200); & \\
\hline radio.begin(); & \\
\hline radio.printDetails(); & \\
\hline radio. setChannel $(0 \times 4 b)$; & \\
\hline radio.setAutoAck $(0)$; & \\
\hline radio.setDataRate (RF24_250KBPS); & \\
\hline radio.setPALevel (RF24_PA_MIN); & \\
\hline Sound.begin(); & \\
\hline
\end{tabular}

Gambar 26 Setting level daya pada IDE arduino

Pada pengujian ini dilakukan pengujian dengan beberapa level daya transmisi yang dapat digunakan oleh NRF24L01. Tabel level daya transmisi ditunjukkan pada tabel .

Tabel Level daya transmisi pada NRF24L01

\begin{tabular}{|c|c|c|}
\hline No & Level & Daya(dBm) \\
\hline 1. & RF24_PA_MIN & -18 \\
\hline 2. & RF24_PA_HIGH & -6 \\
\hline 3. & RF24_PA_MAX & 0 \\
\hline \multicolumn{3}{|c|}{ Sumber : Library NRF24L01 }
\end{tabular}

Setelah melakukan setting level daya yang digunakan, metode pengujian dilakukan dengan cara melakukan intput sample kalimat pada transmitter dan pengencekkan pada sisi receiver dengan menggunakan aplikasi voice to text. Perangkat receiver dihubungkan menggunakan jack 3,5 mm yang dipasangkan pada port mikrofon komputer. Apabila kalimat yang dikirimkan oleh transmitter dapat diterjemahkan oleh aplikasi voice to text dengan benar pada sisi receiver maka proses komunikasi dianggap berhasil. Sample kalimat yang digunakan adalah sebagai "apa kabar" dan "selamat pagi". Skema pengujian ditunjukkan pada gambar 4.10.

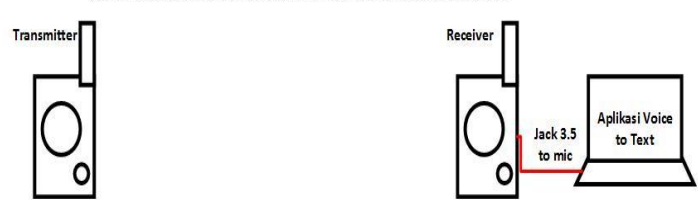

Gambar 27 Skema pengujian pengaruh daya transmisi terhadap jarak jangkauan

Data hasil pengujian maka dapat disederhanakan kedalam grafik yang ditunjukkan pada gambar berikut. 


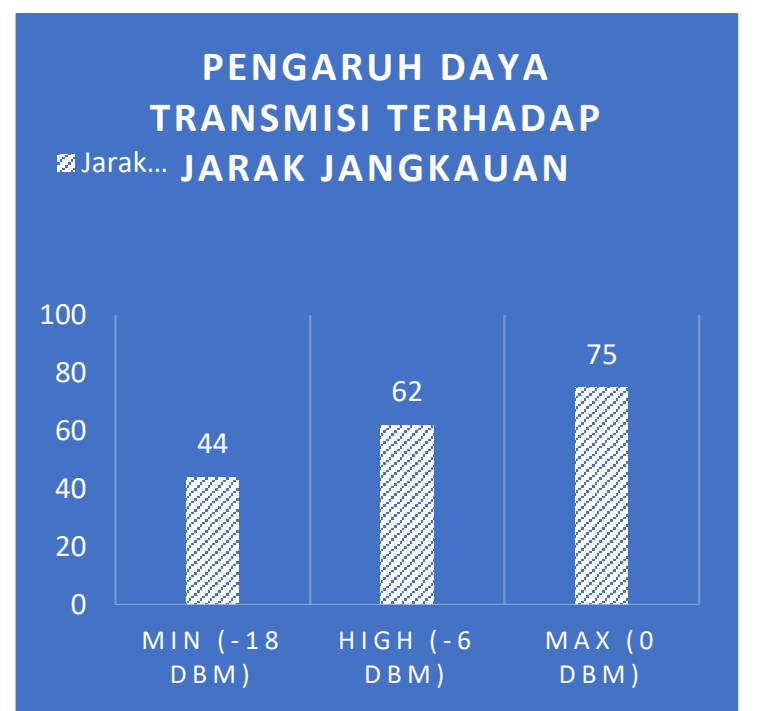

Gambar 28 Grafik pengujian pengaruh daya transmisi terhadap jarak jangkauan sistem

Dari grafik diatas dapat diketahui bahwa saat level daya transmisi terendah MIN $(-18 \mathrm{dBm})$ jarak jangkauan yang dapat dicapai sebesar $44 \mathrm{~m}$, saat level daya $H I G H(-6 \mathrm{dBm})$ jarak yang dapat dicapai sebesar $62 \mathrm{~m}$, dan saat level daya $M A X(0 \mathrm{dBm})$ jarak yang dapat dicapai sebesar $75 \mathrm{~m}$. Dari hasil pengujian tersebut dapat disimpulkan bahwa semakin besar daya transmisi maka semakin jauh jarak jangkauan yang dapat dicapai.

\section{Pengujian sinyal output pada penerima}

Pengujian ini bertujuan untuk mengetahui hasil sinyal output PWM yang telah diterima oleh receiver. Hasil sinyal output PWM dapat diketahui dengan mengamati sinyal output pada penerima dengan menggunakan software audacity. Skema pengujian ditunjukkan pada gambar.

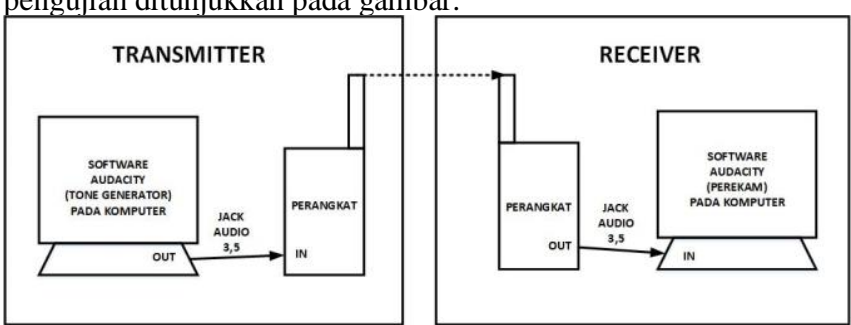

Gambar 29. Skema pengujian kualitas sinyal output PWM

Pada skema diatas, Software audacity pada pengujian ini digunakan sebagai intput tone dan untuk merekam hasil output pada penerima yang diterima oleh receiver. Jack audio 3,5 mm digunakan sebagai penghubung antara perangkat dan computer.

Tampilan awal software audacity ditunjukkan pada gambar.
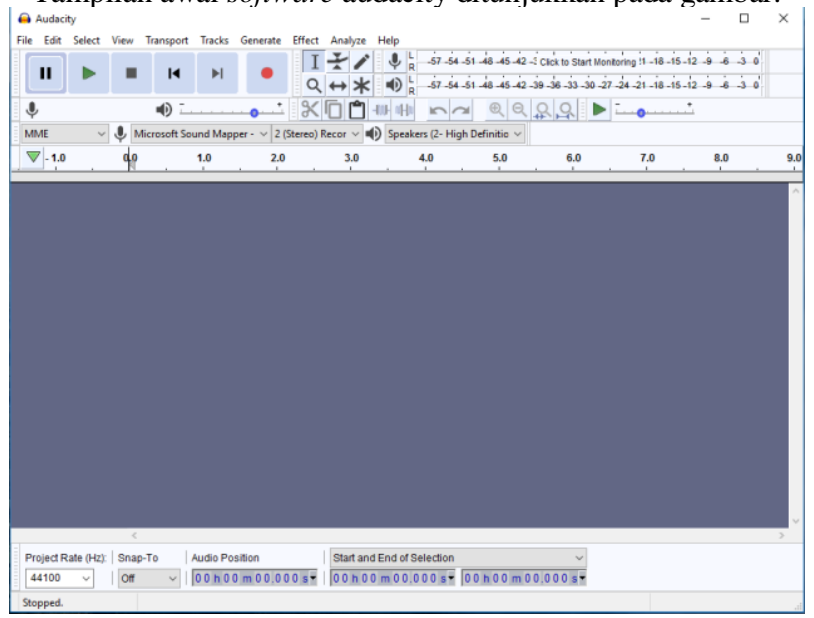

Gambar 30 Tampilan awal software audacity
Langkah awal dalam proses pengujian adalah melakukan generate tone sebagai intput menggunakan software audacity dengan memilih menu Generate $\rightarrow$ Tone. Pada pengujian ini intput tone dengan frekuensi $1 \mathrm{Khz}$ dan amplitudo $2 \mathrm{Vpp}$ dengan durasi 15 detik pada software audacity seperti yang ditunjukkan pada gambar

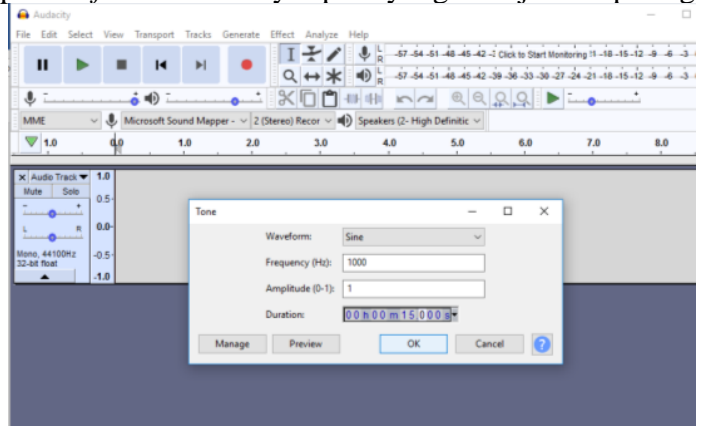

Gambar 31 Generate tone pada software audacity Kemudian pada sisi receiver dipilih menu record dengan icon lingkaran berwarna merah. Sinyal input ditunjukkan pada gambar

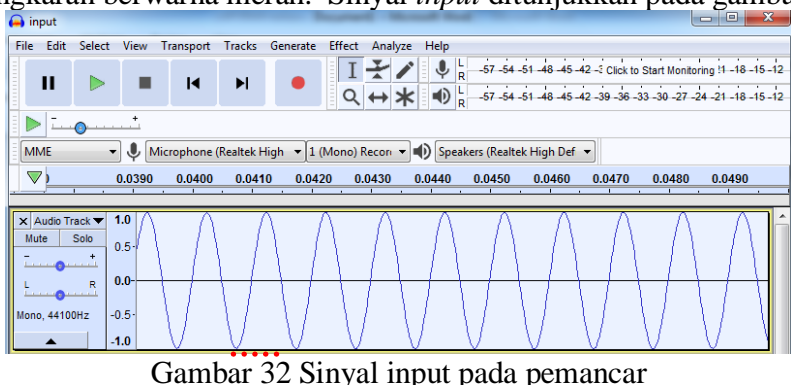

Sedangkan untuk sinyal informasi yang diterima oleh receiver ditunjukkan pada gambar

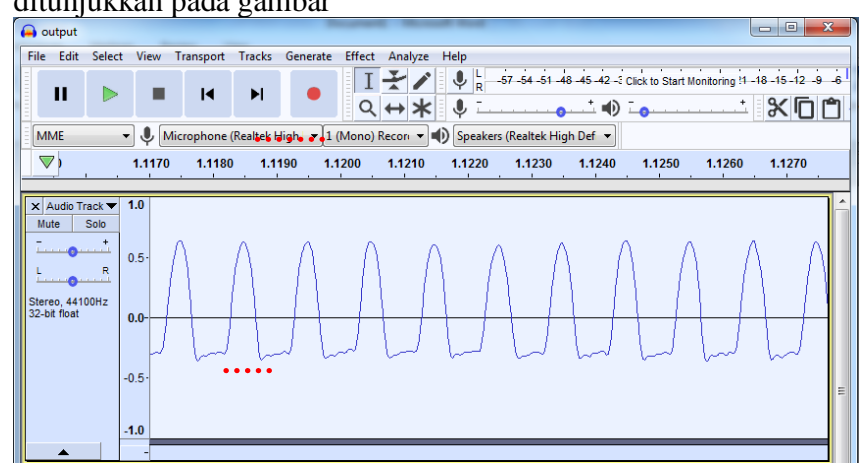

Gambar Sinyal yang diterima pada penerima

Berdasarkah hasil pengujian pada Gambar dapat diketahui bahwa sinyal pada sisi penerima mengalami cacat pada periode negatifnya. Sinyal yang diterima pada sisi penerima mengalami atenuasi. Perhitungan nilai atenuasi tegangan dapat menggunakan rumus :

$$
\begin{gathered}
\mathrm{Av}=20 \log _{10}(\text { Vsumber/ Vtujuan }) \\
\mathrm{Av}=20 \log _{10}(2 \mathrm{Vpp} / 0.9 \mathrm{Vpp}) \\
\mathrm{Av}=6.94 \mathrm{~dB}
\end{gathered}
$$

\section{KESIMPULAN}

Dari hasil pengujian dan pembahasan pada perancangan sistem komunikasi audio digital dua arah pada frekuensi 2,4 ghz dapat diperoleh kesimpulan pembuatan perangkat sistem komunikasi audio digital dua arah pada frekuensi 2,4 Ghz menggunakan mikrokontroler arduino uno dengan sumber tegangan $5 \mathrm{~V}$ sebagai catu daya, mikrofon max9814 sebagai input suara,filter low pass, penguat audio, speaker sebagai perangkat untuk output suara, dan modul radio frekuensi nrf24101 sebagai transceiver untuk komunikasi radio pada frekuensi 2,4 Ghz. Sistem yang dirancang dapat menerjemahkan/menerima macam-macam informasi secara tepat untuk informasi dengan presentase keberhasilan sebesar $100 \%$. Sedangkan untuk sample kata "Jinak" yang mewakili huruf 
"J" masih memiliki tingkat keberhasilan sebesar $60 \%$ karena data yang diterima menjadi kata "china" dan error sebesar $20 \%$ pada sample kata "Udang" yang menjadi "undang". Kualitas informasi audio yang diterima pada penerima masih mengalami cacat pada periode negatifnya. Sinyal yang diterima pada sisi penerima mengalami atenuasi sebesar 6.94dB. Dari hasil pengujian pengaruh datarate terhadap jarak jangkauan dapat disimpulkan bahwa setting data rate $250 \mathrm{Kbps}$ memiliki jarak jangkauan sebesar $75 \mathrm{~m}$ dan pada data rate $1 \mathrm{Mbps}$ memiliki jarak jangkauan sebesar $55 \mathrm{~m}$. Sedangkan untuk hasil pengujian pengaruh daya transmisi terhadap jarak jangkauan dapat disimpulkan bahwa daya transmisi terbesar $(0 \mathrm{dBm})$ memiliki jarak jangkauan terjauh dengan jarak $75 \mathrm{~m}$.

\section{DAFTAR PUSTAKA}

[1] Aldy, T. (2016). Perancangan dan Implementasi Alat Penerima Informasi Radio Menggunakan Mikrokontroler dan Rds dengan Sistem Alarm. Teknik Telekomunikasi Fakultas Ilmu Terapan. Universitas Telkom.

[2] Amry, D. (2015). Kajian implementasi radio siaran digital di Indonesia. Pusat Penelitian dan Pengembangan Sumber Daya dan Perangkat Pos dan Informatika. Jakarta

[3] Kashif, M. Design of An Integrated Gfsk Demodulator For a Bluetooth Receiver. Informatics \& Mathematical Modeling, Technical University Of Denmark, Lyngby, Denmark.

[4] Lili, Q. (2006). Modulation and Demodulation analog basebanddigital. Texas Instruments Inc, Slide 13

[5] Sabih, H. (2016). Implementation of Digital Signal Processing: Some Background on GFSK Modulation. University of Twente, Department of Electrical Engineering.

[6] Datasheet Arduino Uno, Microcontroller board based on the ATmega328P. www.arduino.cc/en/Main/ArduinoBoardUno.

[7] Datasheet NRF24L01, nrf24101 Single Chip 2.4GHz Transceiver Product Specification.https://www.nordicsemi.com/eng/Products/2.4 GHz-RF /nrf24101P

[8] Datasheet MAX9814, Microphone Amplifier with AGC and Low-Noise Microphone Bias. https://datasheets.maximintegrated.com

[9] Datasheet Pam8403, PAM8403 Filterless 3w Class-D Stereo Audio Amplifier, https://www.diodes.com/assets/Datasheets/PAM8403.pdf.

[10] https://ethw.org/Microwave_Link_Networks. Diakses tanggal 20-2-2018 